\title{
As formas literárias e a História
}

\author{
Albertina Vicentini Assumpção \\ abertinhavicentini@uol.com.br \\ Doutora em Teoria Literária e Literatura Comparada pela USP \\ Pós-doutorado em História e Literatura pela UnB \\ Professora do Mestrado em História da Pontifícia Universidade Católica de Goiás
}

\begin{abstract}
Resumo: $O$ artigo discute a relação entre a Literatura e a História em três perspectivas: literatura e sociedade; literatura e mundo representado; e forma literária e material históricocultural. Insiste na relação da História com as formas internas da literatura. Para tanto, avalia o conto "Bonde" de Dalton Trevisan como uma História do tempo presente através das suas formas elípticas e embaralhadas, que absorvem diferentes espacialidades, temporalidades e intertextos.
\end{abstract}

Palavras-chave: Literatura; História; Forma literária.

\section{Literary forms and history}

Abstract: The article discusses the relationship between Literature and History in three perspectives: literature and society; literature and the world represented; and literary form and historical-cultural material. It insists on the relation of History to the internal forms of Literature. To do so, he evaluates Dalton Trevisan's "Bonde" tale as a History of the present time through its elliptic and shuffled forms, which absorb different spatiality, temporalities, and intertexts.

Keywords: Literature; History; Literary form.

As ligações entre a História e a Literatura só foram possíveis porque a História passou, nas últimas décadas, por mudanças e reestruturações que incorporaram novas fontes como possibilidade de acesso a um universo sociocultural de determinado espaço/tempo. Nesse sentido, foi a chamada História Cultural surgida nos anos 60/70 a que, preponderantemente, mais insistiu nessas relações, por se contrapor a uma historiografia até então efetivada a partir do paradigma estruturalista e serial. 
Para essa nova história, importante seriam os "deslocamentos fundamentais das estruturas para as redes, dos sistemas de posições para as situações vividas, das normas coletivas para as estratégias singulares" ${ }^{1}$. Assim, o universo a ser destacado por essa nova história seria encontrado pelo estudo da linguagem, das práticas e das representações, ou seja, práticas discursivas e não discursivas, e dos sujeitos produtores e receptores da cultura, sejam os intelectuais, o leitor solitário ou as massas de leitores, buscando encontrar seus diferentes modos de pensar e de sentir dentro do imaginário social, visível nos símbolos com que essa interação social se manifesta, sem entradas privilegiadas nem exigências prévias.

Foi nessa proposta que entrou a literatura a princípio como fonte privilegiada, plena das chamadas significações/representações da realidade de um tempo.

Não obstante, a entrada na literatura não se deu de forma pacífica, porque a grande questão se resumia na pergunta sobre a validade histórica do discurso literário, um discurso em princípio ficcional, ou seja, que fala do possível e não do real, destituído assim de verdade e legitimidade para servir como fonte de explicação histórica e que já havia sido descartado pela história positivista do final do século XIX. Entretanto, com a defesa do conceito de verdade no plural (verdades) - que propugna que não existe apenas uma versão dos fatos - e com a hora e a vez da história "vista de baixo", história dos homens comuns, a literatura acabou tendo uma entrada, em certo sentido até triunfal, no universo dos pares da História.

Os principais argumentos para sua aceitação centralizaram-se, segundo nos parece, em dois grandes eixos: primeiro, na noção de representação e no fato de que a representação do imaginário social é tão real quanto o fato em si, isto é, a literatura mantém suas bases na matéria social e histórica que representa na obra, sendo assim uma versão da verdade dos acontecimentos. Por meio da verossimilhança, donde se ergue o possível que ela apresenta, a literatura é capaz de significações que apontam um determinado projeto de cultura no interior de determinado grupo social: aponta para o que foi ou era possível de ser verdadeiro (baseada na noção de História herdada de Aristóteles).

Segundo, na questão narrativa ou no fato de essas representações se exporem por meio de acontecimentos configurados numa ordem no mínimo coerente (uma ordem no heterogêneo), configurando um história/estória e que envolve a questão da temporalidade,

\footnotetext{
${ }^{1}$ CHARTIER, Roger. A História cultural - entre práticas e representações. Lisboa; Rio de Janeiro: Difel; Bertrand do Brasil, 1990, p. 98.
} 
no caso estreitamente ligada à própria narrativa - o único modo de se perceber o tempo é enfeixá-lo numa narrativa, assegura Paul Ricouer. ${ }^{2}$

De outro lado, deve existir uma prática do historiador decorrente desses diferentes tratamentos narrativos e de representação da realidade, na linha mesma da observação das noções de rede, das situações vividas e das estratégias singulares, representações do imaginário, configuração narrativa. Disso decorre uma indagação: será que essa investigação ou prática do historiador deve ser mais atinente aos elementos de análise de conteúdo, que se situam na avaliação da estória contada, dos personagens, da coesão interna do texto, da verossimilhança, da plausibilidade? A literatura seria representação da sociedade e da História sobretudo porque expõe conteúdos do imaginário, dos valores de um tempo, mesmo que sob a forma fictícia? Ou a questão da literatura enquanto forma também deve estar em jogo? E mais: como a literatura pode ultrapassar o fictício que a constitui para de fato passar a ser um dado histórico real e verídico, comprovável - uma explicação histórica?

Parece-nos que uma resposta deve ser dada a partir de uma abordagem diferenciada da obra literária que passa, fundamentalmente, entre outras, pelas relações que se seguem. Primeiro, as relações literatura e sociedade, ou seja, relações externas à obra, configuradas pelo contexto social, político e cultural em que ela se insere: pesquisa da sua autoria - quem é o autor -; quais suas posturas estéticas, sociais e políticas; como foi sua recepção ao tempo e ao longo do tempo; o que já se disse dessa obra e do conjunto de obra do escritor (verificação da crítica, do leitor, das classes sociais às quais se dirigiu etc.).

Segundo, as relações literatura e universo criado ou mundo representado, isto é, relações externas às quais a obra remete através da história contada, dos personagens de que ela fala, o que representam, a qual realidade externa a obra remete, quais os comportamentos sociais, psicológicos e culturais assegurados, qual a temporalidade dos acontecimentos, em qual espaço etc.

E, terceiro, as relações internas à obra, ou seja, a relação da forma literária com a forma material-histórico-social com que ela (a obra) figura no universo social: sua

\footnotetext{
2 RICOEUR, Paul. Tempo e narrativa. Campinas, São Paulo: Papirus, 1997.
} 
estruturação de temas, seu trabalho com a temporalidade interna à história, o trabalho linguístico das frases e das diferentes vozes e narrações etc.

A primeira - literatura e sociedade - assegura ao historiador o entorno da obra, promove a segurança do universo em que foi produzida: contexto social, resposta a indagações do tempo presente, necessidades sociais do tempo da obra, seus processos estéticos, sua distribuição, sua recepção etc. O único risco dessa verificação é sair da História e entrar na sociologia ou no sociologismo da literatura.

A segunda, literatura e mundo representado - que já lida com elementos da obra propriamente ditos -, assegura a verificação dos comportamentos, da intriga, dos valores, dos afetos, das contradições, do imaginário, das sensibilidades sociais do tempo-espaço focalizado na obra. O seu perigo é o de se transformar numa análise meramente conteudística da obra literária.

A última (que, no nosso modo de ver, é às vezes negligenciada pelo historiador), revela a produção propriamente dita do texto e é a que, julgamos, possibilita invalidar a questão do fictício como entrave das relações entre a História e a Literatura. Dizemos isso porque uma obra literária pode, por exemplo, falar de outro imaginário de outro tempo que não aquele em que foi escrita (o que releva a "pesquisa" do escritor em relação a esse tempo focalizado), e isso significa que restará dela somente a sua forma literária para comprovar o seu próprio tempo. Daí a sua importância e razão.

Ademais, é a forma em que o imaginário retratado pela obra está que pode fazer dela uma obra literária e não uma obra jornalística, por exemplo.

A forma literária é material sócio-histórico sedimentado, como afirma Adorno ${ }^{3}$. Em outras palavras, nesse sentido, o que a literatura na realidade faz é formalizar significados e valores da sociedade no ato mesmo e no modo mesmo de sua apresentação. É isso que também a faz ser uma representação da sociedade (não porque a imita, ou é dela um reflexo, ou porque expõe um imaginário de um tempo histórico), mas porque a formaliza e se formaliza nela, isto é, ela, enquanto tal, é uma forma histórica como outra qualquer, que constitui a sociedade e é constituída por ela. O que a diferencia das outras formas é o que

\footnotetext{
${ }^{3}$ ADORNO, Theodor. "Palestra sobre lírica e sociedade". Editora 34, 2003.
} Notas de literatura I. São Paulo: Duas Cidades; 
Foucault ${ }^{4}$ chamou de formação discursiva, melhor dizendo, ela difere por se inserir, dentro da ordem do discurso, em uma formação discursiva outra que não a dos jornais ou da ciência, por exemplo. Isso implica que a forma como se apresentam os acontecimentos dentro de uma obra literária, como se apresenta o narrador, como se apresentam as suas metáforas, suas descrições, seu conteúdo (e há uma substância de conteúdo que é a matéria narrada, mas também há uma forma de conteúdo que é como essa matéria se dispõe no texto) etc. são, ao lado dos eventos ou dos sentimentos selecionados do conteúdo materializado, aquilo que também investe o sentido do texto e o planta na sociedade como uma representação. Está certo Roberto Schwarz ${ }^{5}$ quando diz que são as formas materiais da vida concreta que trabalham as formas da literatura. As formas nascem num tempo e só nasceriam no tempo que manifestam (mesmo quando precursionam um tempo futuro ou falam de um passado). Elas manifestam tanto as possibilidades, as potencialidades quanto as limitações de seu próprio tempo. Elas são emblemas, alegorias de um tempo (para retomar aqui Benjamin ${ }^{6}$ ), porque manifestam recursos formais que o denotam, denunciam, independentemente dos conteúdos que possam veicular, ou das manifestações intencionais de seu autor. [Uma obra anônima ou em ruínas, de que só sobraram fragmentos pouco legíveis, indicam, sem sombra de dúvida, o tempo em que foram escritas pelos seus recursos linguísticos, estilística, vocabulário; pelos seus modos de estruturação de referência e de tempo, modos de apresentação; sintaxe, processos discursivos, tons, modulações, modalidades; ordenamento do texto, conteúdo selecionado etc. Todos são elementos indiciais fundamentais da sociedade em que a obra se insere.] Denotam a semântica de um tempo, representam-no bem mais, inclusive, do que os conteúdos veiculados, até porque, constituída nesse tempo, ela também o constitui.

A título de exemplo, podemos tomar a literatura de base realista - tão cara aos historiadores. Mais tradicional e próxima do referente, esse é um tipo de literatura que coincide com o final do século XIX e, dada a proeminência da História para a classe burguesa desse tempo e o próprio entendimento do que era a História enquanto temporalidade -

\footnotetext{
${ }^{4}$ FOUCAULT, Michel. Arqueologia do saber. 7 ed. Rio de Janeiro: Forense Universitária, 2007.

${ }^{5}$ Apud CEVASCO, M.E. "O diferencial da crítica materialista". Ideias, Campinas (SP), n.7, nova série, 2o. semestre, 2013.

${ }^{6}$ BENJAMIN, Walter. Obras escolhidas. 3 ed. São Paulo: Brasiliense, 1987.
} 
sucessão de acontecimentos em causas e efeitos -, trata o tempo de forma mais linear, sucessiva, esforçando-se ao máximo para cumprir a cronologia dos acontecimentos, utilizando-se dos variados recursos que detém para isso: os flashbacks, quando completa as lacunas da intriga; os advérbios de tempo: "enquanto isso", os "ao mesmo tempo", os "hoje, amanhã, depois, duas semanas depois, três anos mais tarde" etc.

Na narrativa desse tipo de romance de até o final do século XIX foi esse o tratamento que preponderou, até porque servia aos fins narrativos - o de mostrar a sociedade e a lógica humana a partir de um só plano, o social. Buscando a experiência imediatamente comunicável e observável, passava ao leitor que existe uma só realidade, a mesma para todos, e a narrativa do romance tinha de dar conta dela assim como a História. O romancista acreditava pintar a realidade, só que sua visão não era a de um homem que vê simplesmente, mas a de um observador, de um professor afeiçoado a problemas. Tudo era contado, narrado, explicado, com personagens coerentes, criados para convir a uma intriga. Mesmo quando avaliava psicologicamente seus personagens, estes não revelavam a ambiguidade de seu presente; antes, escamoteavam-na. A análise da psique era racional, feita a partir de um ponto de vista, e os personagens, mesmo analisados psicologicamente, eram submetidos à intriga. Esse foi o modo de narrar de Balzac, de Flaubert, de Stendhal, de Machado de Assis, de Eça de Queirós, de Alencar e tantos mais. Inversões e rupturas desse tempo cronológico poderiam acontecer (como o defunto-autor Brás Cubas), mas logo a narrativa recuperava a cronologia dos acontecimentos em sua coerência e clareza quantitativas. ${ }^{7}$

Já em uma obra como Perto do coração selvagem ou $A$ paixão segundo $G H$, de Clarice Lispector, o que se busca pertence a outra ordem. Melhor dizendo, pertence à literatura já do século XX, ou seja, pertence não à ordem, mas à desordem, à dispersão do mundo interior, com personagens indecisos, difíceis de manejar. Se esses personagens são avaliados psicologicamente, essa análise não é uma verdade objetiva, mas uma tentativa desesperada, infinita, uma vertigem de compreensão. O leitor não progride na compreensão do personagem à medida que a narrativa se desenvolve. Ao contrário, a personalidade deste vai ficando cada vez mais desconcertante, enigmática, ambígua. Um quebra-cabeça. E nada nos é comentado. Não temos mais um professor nessa história. E porque não desenvolve mais um

\footnotetext{
${ }^{7}$ ALBÉRÈS, Michel. Histoire du roman moderne. Paris: Albin Michel, 1962. (Tradução compilada de Albertina Vicentini).
} 
tema psicológico ou social, o romancista evoca a confusão do real, descobrindo para o leitor espessuras diferentes em diferentes planos da vida humana. A coerência e a lógica desaparecem no relativismo da dispersão. No lugar dos fatos, das coisas e dos homens aparecem as relações entre eles, através dos pontos de vista que se multiplicam. A estória/intriga/enredo se reduz ao mínimo.

A temporalidade de uma obra como essa é a da duração desigual de pouco tempo, um dia, uma hora, uma visita, um encontro, porque a experiência não é contada, mas vivida, e essa experiência é ambígua e ambos, experiência e ambiguidade, são retidos, porque essa é a matéria dessa narrativa. Não é o social ou o psicológico, porque ambos são matérias desconhecidas pelo narrador: não se conhecem mais os mecanismos sociais ou psicológicos. O que nos é narrado é o tempo vivido de uma experiência desconcertante, enigmática. E ela se resolve quase sempre através de Kairos $^{8}$, de uma temporalidade instantânea em que culmina a personagem num momento de revelação, ou de epifania, como se diz em teoria literária, momento que busca a fusão do tempo da história, com o tempo da escrita e o tempo da leitura. De repente, tudo se esclarece para o personagem pelo menos no instante da epifania: um momento de simultaneidade e resolução de todas as angústias e conflitos que a narrativa gastou tempo e discurso para expor. Um momento oportuno, mas só um momento. Depois dele, nada mais dura e tudo pode, inclusive, se embaralhar de novo.

Essa forma literária embaralhada é uma forma que aponta para a individualidade crescente e fragmentada dos dias atuais, forma da descentralização do sujeito unitário dentro de um tempo em que se perdeu o sentido da História ou, pelo menos de que não se participa mais de sua construção, e cujo sentido só pode ser recuperado por instantes efêmeros ou epifânicos.

Mas outras obras há ainda que não desordenam nem dispersam o tempo linear e suas durações, mas quebram a verossimilhança e a temporalidade de outra forma, ou seja, na convocação de um plano simbólico, meio atemporal, meio de parábola ou de fábula ou de mitos, alegorias abstratas, aderindo ao tempo circular das narrativas primevas, ou das formas

\footnotetext{
${ }^{8}$ A temporalidade, desde os gregos, se manifesta de pelo menos três formas: o tempo cronológico, quantificável no relógio e em sequência linear, denominado Cronos; o tempo cíclico, atemporal porque repetível, intocável e eterno, sempre recomeçando, denominado Aion; e o tempo do instante, qualitativo, ligado à experiência do agente que deve agir de imediato, no "momento oportuno", mas sem duração, denominado Kairos. (Apud WEINHARDT, Marilene. "Romance histórico: das origens escocesas ao Brasil finissecular". (org.) Fiç̧ão histórica: teoria e crítica. Ponta Grossa: UEPG, 2011).
} 
mínimas de André Jolles ${ }^{9}$. Aqui o tempo é circular porque é eterno, como nos contos populares ou nessas formas simples da legenda, da saga, do mito, das fábulas, que sobrevivem justamente porque transcendem a temporalidade do real, conforme assinala Weinhardt. ${ }^{10}$ Embora subvertendo o real e colocando-se em confronto com a História, querem, no entanto, como essa, a História, produzir uma verdade acerca da sociedade ou do sujeito ou de comportamentos etc. Querem a verdade, como a História. Alinham-se com os provérbios, as máximas, os aforismos, cujo resultado é sempre uma sabedoria a ser transmitida. Obras como o Ensaio sobre a cegueira, de José Saramago, ou O processo, de Franz Kafka, ou Cem anos de solidão, de Gabriel García Marques, encaixam-se perfeitamente nesse tratamento de temporalidade. Obras que revelam o heterogêneo, o misturado, o mestiço deste nosso tempo.

Há também as narrativas que suspendem a temporalidade do relato para entrar com outra temporalidade: a do ensaio ou da metalinguagem, a que chamamos de narrativas narcísicas, porque se autoexplicam enquanto relatam. Paludes, de André Gide, cujo tema é a escrita do romance Paludes, desenvolve essa forma, ou seja, a forma das narrativas que se autoespelham.

Há ainda as narrativas (como as de Jorge Luis Borges) que embaralham informações corretas e incorretas, diferentes temporalidades e diferentes autores, apropriando-se de anacronismos deliberadamente.

E tantas mais, todas ligadas, por sua fatura, a um tempo.

Isso significa que há uma ligação umbilical entre as formas da literatura e a História que elas concretizam e isso independentemente de o universo literário ser fictício, construído ou inventado, ser narrativo ou não.

$\mathrm{Na}$ "Dialética da malandragem", quando, em 1970, analisa Memórias de um sargento de milícias, de Manoel Antonio de Almeida, Antonio Candido elabora uma categoria para dar conta disso que estamos falando: a reversibilidade entre forma social e forma literária. Dizia ele, desde 1961, em Literatura e sociedade ${ }^{11}$ (e essa é uma postura muito bem falada, mas pouco realizada), que o externo (no caso o social) importa não como causa, nem como

\footnotetext{
9 JOLLES, André. Formas Simples. São Paulo: Cultrix, 1978.

${ }^{10}$ WEINHARDT, op. cit.

11 CANDIDO, Antonio. "Dialética da malandragem". Disponível em: http://www.revistas.usp.br/rieb/article/view/69638. Acesso em 13 de maio 2016.
} 
significado, mas como elemento que desempenha um papel na constituição da estrutura da obra, tornando-se, portanto, interno. Ou seja, a forma da obra é a configuração de uma lógica social. A crítica deve saber desvendar essa lógica dentro de seu funcionamento específico, o que a impele a avaliar a literatura como uma dialética entre a sócio-história e a obra e não como reflexo do que previamente já se sabe da história social e que se aplica à literatura. A forma é dada aqui como uma condensação do real. Buscá-la é achar esse real que a sedimenta. Melhor dizendo, a forma envolve tanto a representação quanto a configuração narrativa e a configuração discursiva, especialmente quanto à disposição dos elementos do tema no texto.

Para ilustrar, tomemos um pequeno conto de Dalton Trevisan, de 1968, intitulado "Bonde":

Solteiro, comerciário, ele se desespera na fila das seis da tarde. Na meia hora de vida roubada por esse bonde, José podia ter feito grandes coisas: beber rum da Jamaica, beijar Mercedes, saquear uma ilha. Pula de um pé no outro, impaciente de assumir o seu posto no mundo, assim que o bonde chegue - o navio fantasma fundeia nos verdes olhos.

Não dói o calo no pé esquerdo, nem pesa o guarda-chuva no braço, a um flibusteiro que bebe rum em crânio humano daria o Capitão Kidd desconto de $3 \%$ de vendas à vista? Desafia os vagalhões de sua nau Catarineta, eis que o pirata lhe bateu no braço e o herói saltou em terra.

- Seu moço, pra onde vai esse bonde?

- Por cem milhões de percevejos fedorentos!

Bom rapaz, não praguejou feito um excomungado lobo-do-mar, e deu a rota de sua fragata. Um moço - vinte anos, puxa! - com a idade do homem de negócios, o guarda-chuva é negra bandeira de tíbias cruzadas. Nesse bonde que ninguém não viu, ele quer fugir para o longe, abandonando a donzela de cigarro na boca, triste no cais. A seu lado o barbudo Zequinha Perna-de Pau e a pálida filha do Vice-Rei das Tartarugas bóiam, náufragos como ele, atirados à praia pela maré. O velho de olhos azuis de contramestre, um pacote de bananas no braço, sorri pra ele. Na testa lateja uma espinha, até isso!

Morte aos barões cornudos! Desfralda no crepúsculo o seu grito de guerra. Todo velhote é um canhão de museu, sente gana de afogar o Corsário Mão-de-Gancho que o não deixa se fazer ao mar. Corpo de cavalo-marinho, uma dama igual àquela, triste no cais, sopra inquietos ventos nas velas rotas de seu bergantim. Arrasta as correntes de âncora que enleia a partida: piedade filial, temor a Deus, devoção à pátria.

Em vão vogava em maré de barataria, o bonde que chega abriu a goela de baleia, onde Jonas esperava por ele com um barril de rum.

A consciência de sua idade lhe dói no calo do pé, na espinha da testa, nas vozes de sereias que cantam só para ele. A maruja iça a bujarrona e o velho tropeça no estribo, derrubando o pacote. Sem orgulho ou dignidade, o pirata recolheu as bananas amassadas e subiu, perdido o último banco da popa. 
O bonde joga no mar grosso, dele não se pode ver o céu. O contramestre retira uma banana do pacote, é a segunda vez que oferece. De pé, no cesto da gávea, grita o Capitão - "Terra!", os telhados de Ítaca tremulando ao longe. ${ }^{12}$

Referencialmente, o texto relata a espera de um bonde, a sua chegada, o embarque de passageiros, entre eles José, rapaz novo, comerciário, solteiro, impaciente por já esperar meia hora na fila e por já estar na idade de um "homem de negócios", mas ainda não ser um "homem de negócios" [tinha até espinha na testa]. Nesse compasso de espera, começa a fantasiar-se pirata de uma nau-fantasma [Catarineta], quando é interrompido por outro passageiro que lhe pergunta a respeito do trajeto do bonde. Irrita-se com a interrupção da fantasia, mas dá a rota do bonde a quem o perguntou. E continua a imaginar: o guarda-chuva torna-se a bandeira pirata, os passageiros também à espera na fila tornam-se seus tripulantes [o barbudo Zequinha Perna-de-Pau], contramestre [o velho de olhos azuis com um "pacote de bananas no braço"], a mocinha donzela dos filmes e livros de pirataria [filha do Vice-Rei das Tartarugas] e uma primeira cena dessa aventura acontece: "náufragos, atirados à praia".

A seguir, outra cena de aventura, esta de guerra ["Morte aos barões cornudos! Desfralda no crepúsculo o seu grito de guerra."] contra o Corsário Mão-de-Gancho que o impede de partir. Os bons ventos vêm e ele iça a âncora, não sem antes emitir a sua ética ["piedade filial, temor a Deus, devoção à pátria."]

Chega o bonde, todos embarcam em alvoroço, o velho ao seu lado tropeça, o pacote de bananas cai, o velho o recolhe e sobe, sem conseguir se sentar.

No bonde, oferece uma banana a José pela segunda vez, e todos partem para o seu destino/aventura. O destino de José é Ítaca, isto é, sua casa.

O imaginário selecionado (e atenção para a seleção) pertence a um tempo não muito distante do nosso, mas que já guarda muito do que hoje temos: a vida urbana atarefada e sofrida nas filas do transporte coletivo, no caso, o bonde, pai dos coletivos urbanos atuais. Também os intertextos apontam outro imaginário atual: Perna-de-Pau, Capitão Kidd (pirata histórico que morre em 1701), Corsário Mão-de-Gancho, donzela romântica, remetem-nos a livros de aventuras ao mar, pirataria, filmes de pirata, Disney etc.

\footnotetext{
12 TREVISAN, Dalton. Desastres do amor. Rio de Janeiro: Civilização Brasileira, 1968.
} 
O intertexto bíblico é mais remoto: o de Jonas - o pecador engolido por uma baleia onde viveu por dias. O quarto intertexto também é remoto: é homérico, representado por Ítaca (pátria de Odisseu) e as sereias, episódio da Odisséia de Homero, quando da volta de Odisseu (ou Ulisses) para casa, Ítaca, pelo mar, após a Guerra de Tróia. Na mesma linha, só que agora medieval, a nau Catarineta - esses três últimos índices da erudição do narrador, que contrasta com as fantasias do personagem.

Tanto a espera quanto a fantasia remetem à ansiedade que experimenta o homem das cidades grandes, o homem urbano: uma pela realidade da fila; a outra, pela fantasia como fuga e tentativa de se salvar dessa vida rotineira e ansiosa ["Nesse bonde que ninguém viu, ele quer fugir para o longe".]

O imaginário desses conflitos comporta ainda irritações ["Por cem milhões de percevejos fedorentos!"], dúvidas e preocupações [..."daria o Capitão Kidd desconto de 3\% de desconto à vista?"], frustrações [“Um moço - vinte anos, puxa! - com a idade do homem de negócios"..], impaciência ["Pula de um pé no outro.."] - todos índices do estresse e da frustração desse cotidiano pífio e sofrido [“Na testa lateja uma espinha, até isso!"]

As duas grandes metáforas do texto - o bonde - como baleia e como navio grande, que comporta vários "tripulantes" apertados [embora de dentro "dele não se pode (possa) ver o céu"] - e o mar - os 'trilhos' por onde se navega ou se viaja - são coerentes, o que denota a fantasia de José como pertinente, apontando sua racionalidade analógica, condizente com sua idade de rapaz jovem, nível intelectual baixo, condição socioeconômica de classe média baixa.

Essa temática desenvolvida por Trevisan está, de outro lado, numa forma bastante peculiar: primeiro, a temporalidade. Num nível primário, a temporalidade é linear e sequencial - uma fila de espera pelo bonde, a chegada do bonde, o embarque, a chegada ao destino. Só que outras temporalidades se cruzam nessa sequenciação, dadas pelas fantasias de José, ou temporalidades intertextuais: a nau, na Idade Média, Homero, na Antiguidade, Jonas no tempo bíblico e os piratas no tempo do maravilhoso.

Depois, o espaço: o da fila, o do bonde e o outro espaço da fantasia: a praia, o alto mar, o navio, o cais.

Ainda, no mundo representado: o mundo supostamente real, onde se localizam os atos de esperar, de responder uma pergunta, de cair bananas ao chão etc. e o mundo da fantasia de pirataria, um mundo intangível, mundo dos pensamentos de José. 
E, finalmente, a forma elíptica: nada é introduzido, não há descrições informativas, não há paradas narrativas que nos informem sobre os personagens ou sobre a estória etc. Como nada é comentado ou explicitado, a narrativa do conto acaba, mais do que entrecruzando, embaralhando essas representações, que acabam se tornando um quebra-cabeças ao leitor, que fica sem saber direito o que acontece no conto.

No nível formal, essa é a forma com que os media têm nos bombardeado diariamente, a forma do videoclipe, por exemplo, ou da televisão (o conto é dos anos 60), que embaralha tempos, espaços, mundos representados, emblemas, sinais, bandeiras... de forma ininterrupta, rápida e elíptica. Zapear na televisão, ou mesmo que estejamos vendo um só canal, sejam os cortes de uma propaganda para outra, sejam os noticiários de um assunto ou de um espaço para outro, sejam as pequenas narrativas dos videoclipes ou o embaralhamento de imagens de diferentes teores ou procedência, o que temos é quadro, um sintético panorama de algo que não sabemos bem o que é.

Ao nível de uma leitura histórica dessas formas, estamos em um tempo em que o acontecimento não acontece, ou pelo menos não se vivencia nada a esse respeito. $\mathrm{O}$ conto de Trevisan sequer chega a contar uma estória. Aliás, não há intriga, tem-se mais um pretexto de enredo do que um enredo propriamente dito. Essa ausência aponta para uma História que vemos na televisão, lemos no jornal, mas que está distante de nós como se dela não fizéssemos parte, como diz Schneider: ${ }^{13}$

(...) deparo com ela (a História) principalmente dentro das minhas quatro paredes. Isto não quer dizer que nada de importante me aconteça (...) mas seja o que for que eu faça e sofra, não tem absolutamente nada a ver com a grande história que acontece diariamente (...) nunca me encontro no meio dos ditos acontecimentos. Deus sabe que não pretendo queixar-me disso, apenas me interrogo: em que consiste, na realidade, a minha participação na História?

Por isso, José, um homem comum e insignificante, fantasia outros tempos e espaços: é uma forma de dar sentido ao que não tem sentido. Onde sua participação em "histórias da vida real"? Melhor fantasiar.

\footnotetext{
${ }^{13}$ SCHNEIDER, Peter. "A luz no fim do narrar". SERUYA, Teresa (org.). Sobre o romance no século XX. Lisboa: Colibri,
} 1995, p. 121. 
A História hoje não se faz mais coletivamente, mas de forma reduzida em escritórios e bancos, em governos e parlamentos. No fundo, há só pequenas histórias paralelas e refratárias, histórias que nem são histórias, como as de José, pegando o bonde às seis da tarde de volta para casa após o trabalho rotineiro que tem.

Insistimos nessa questão porque, quando a relação a ser avaliada se prende exclusivamente às relações que a obra mantém com seus conteúdos veiculados - caso da relação entre literatura e mundo representado -, o que se busca é simplesmente uma correspondência entre o que a obra diz ficticiamente - seus temas, seus personagens etc. - e o real, ou seja, sua referencialidade, impondo uma correspondência direta entre a obra literária e a realidade, esquecendo-se, inclusive, da não universalidade do conceito de ficção e da própria historicidade/variabilidade do trinômio autor/obra/público. Aliás, é em cima da referencialidade enquanto realidade que o discutido tema da História x ficção ganha relevo: a literatura seria ficcional (invenção de um mundo), embora trabalhe com o verossímil (inserção do real/referencial) interno e externo à obra. No entanto, imita, mas não é a realidade. A História, ao contrário, seria a "verdade" do real a partir de uma transparência/exatidão referencial, sendo esta uma das razões pelas quais a historiografia do século XIX repudiou a literatura como fonte histórica.

Nos estudos atuais, desde o Roland Barthes do ensaio "Da história ao real" ${ }^{14}$, de 1967, ou de Northrop Frye do "Novas direções do passado"15, de 1963, enfatizado posteriormente por Hayden White ${ }^{16}$ e Paul Veyne ${ }^{17}$ (1987), a ficção deixou de ser um monstro literário para a História. Foi-lhe dado um cadinho de imaginação literária. Só que o cadinho de ficção que coube à História, no entanto, compareceu e comparece ainda aprisionado pela imaginação restrita ${ }^{18}$, mera preenchedora de espaços ou lacunas nos fatos por indução ou retrodicção; ou comparece nos processos de seleção e encaminhamento narrativo, no caso, inclusive dados como autorais. Sempre, entretanto, circundada pelos documentos, pelos arquivos e fontes

\footnotetext{
14 BARTHES, Roland. "Da História ao real"; "O efeito do real". O rumor da língua. São Paulo: Martins Fontes, 2004

15 FRYE, Northrop. "Novas direções do passado"; "O imaginativo e o imaginário". Fábulas de identidade. São Paulo: Nova Alexandria, 2000.

${ }^{16}$ WHITE, Hayden. Meta-história: a imaginação histórica do século XIX. São Paulo: Edusp, 1992

${ }^{17}$ VEYNE, Paul. Como se escreve a História. Lisboa: Edições 70, 1987.

18 Frye diria, no ensaio "O imaginativo e o imaginário", ainda em Fábulas de identidade, p.167 a 184: uma imaginação ainda presa ao senso, isto é, uma imaginação guiada pelo reconhecimento das coisas que se veem e não a imaginação criativa que vê "um modelo invisível de algo não existente".
} 
decididamente existentes na realidade (e referenciais/reais, portanto, por sua própria natureza), e por uma metodologia historiográfica bem dominada pelo historiador. Desses apetrechos finais - documentos e metodologia - resulta sempre um discurso efetuado de modo institucional, ao qual se impõem restrições, conforme apregoa Michel De Certeau. ${ }^{19}$

O maior perigo do apego a essa referencialidade, porém, fica à vista: a empresa entre a palavra e o mundo não pode se manter na prática de ver a literatura como fonte histórica, especialmente porque tal exigência mantém a literatura exclusivamente nos moldes da literatura realista do século XIX que, na teoria literária, não passa de uma convenção, isto é, não considera que, de fato, a ficção não tem nenhuma 'essência' verdadeira e, nesse sentido, não pode ser 'documento' da realidade, além de não se esgotar na adequação ou não da representação literária à realidade. O conhecido "efeito de real" de que nos fala Roland Barthes $^{20}$ não pode ser o requisito principal para esse tipo de avaliação de fonte, não somente porque é convenção, mas também porque, de outro lado, a questão da "correspondência" do discurso com a realidade são águas passadas. Não que o referente inexista, como querem os pós-estruturalistas e pós-modernistas, mas porque ele hoje é encarado de outra maneira.

Para os pós-estruturalistas e pós-modernos, não existe uma relação causal entre o discurso e a realidade, o que nos permite falar, como diz Cardoso ${ }^{21}$, de um terceiro deslocamento da própria referência (o primeiro veio com Ferdinand de Saussure ${ }^{22}$, no início do século XX; o segundo pela linguística da enunciação, aberta por Émile Benveniste ${ }^{23}$, em meados do mesmo século), qual seja: a de que, segundo eles (os pós-estruturalistas e pósmodernos), aquilo que chamamos de realidade é um constructo de nosso discurso.

Claro, esse é o contraponto mais distante dessa "correspondência com a realidade" que o signo linguístico clássico apontava e é, em si, um contraponto radical de muito pouco proveito. Conforme indaga Cardoso: ${ }^{24}$

Se toda referência é construída discursivamente, qual seria então a validade objetiva do discurso? Ou, conforme coloca Eagleton (1997, original em inglês de 1991) (...), "o que restringe nossas construções

\footnotetext{
${ }^{19}$ DE CERTEAU, Michel. A escrita da História. 2 ed. Rio de Janeiro: Forense Universitária, 2008.

20 BARTHES, Roland. "O efeito do real”. ___ . O rumor da língua. São Paulo: Martins Fontes, 2004.

${ }^{21}$ CARDOSO, Sílvia Helena Barbi. A questão da referência. Campinas, SP: Autores Associados, 2003.

22 SAUSSURE, Ferdinand. Curso de linguística geral. São Paulo: Cultrix, 1972.

23 BENVENISTE, Émile. "O aparelho formal da enunciação." São Paulo: Pontes, 1989.

${ }^{24}$ CARDOSO, op. cit., p. 117-118.
} 
discursivas? Seria mesmo possível falarmos, em qualquer lugar, aquilo que nos vem à cabeça?"

O que fazem os pós-modernos, de certa maneira, é inverter "a relação entre o significado e o significante (agora é o significante que determina o significado, ou melhor, que o constrói)" 25 e exibir uma confusão semiótica entre significado e referente, com o referente sendo igual ao significado - o que equivale a dizer que é elidido (e nesse sentido perde-se, inclusive o conceito de representação que o signo anteriormente abraçava, que era o de estabelecer uma significação entre algo e algo diferente - um tema caro à História). “No lugar de um referente ou objeto do mundo (sendo significado de maneiras diferentes pelos signos da linguagem), fica-se apenas com um significado "produzido" e um significante "produtor". ${ }^{26}$

Segundo Eagleton ${ }^{27}$, se não é mais possível aceitar uma epistemologia que presume alguma correspondência entre nossos conceitos e aquilo que o mundo é (com o significado preexistindo ao significante, obedientemente refletido por ele), também não se pode aceitar que ele seja mero produto do significante, que não exista uma realidade para além do domínio do discurso. "O real existe antes e independentemente do discurso, podendo-se considerar o real como o conjunto específico de práticas que oferecem a razão (não a causa) para o que se diz e constituem o seu referencial. Essas práticas são transformadas interpretativamente." 28

Interpretativamente quer dizer: o signo garante um terceiro termo, o referente, que pode ser refratado por outros significados dados pelo próprio signo. Numa espiral, o referente transforma-se em signo que aponta significados que ultrapassam suas próprias particularidades, princípio, inclusive da leitura polissêmica. Sua forma não se fixa num conteúdo exclusivo, já que outras e novas significações podem surgir. Isso revela que o signo é um fragmento material da realidade, um fenômeno do mundo exterior (tanto é que é fisicamente realizado) e interfere na realidade tanto quanto sofre os efeitos provenientes de suas transformações. O estudo dessa face atual do signo é levada hoje pela Análise do Discurso $(A D)$, inclusive com o projeto político da leitura de que todo signo é ideológico, como proferiu Bakhtin. ${ }^{29}$

\footnotetext{
25 Ibidem, p.118.

${ }^{26}$ Idem.

27 EAGLETON, Terry. Ideologia. Uma introdução. São Paulo: Unesp, 1997.

${ }^{28}$ CARDOSO, op. cit., p. 119.

${ }^{29}$ BAKHTIN, Mikhail. Marxismo e filosofia da linguagem. 12 ed. São Paulo: Hucitec, 2006.
} 
Mas a História não pode se restringir a análises discursivas do acontecimento (isso é tarefa da Linguística), mesmo que seu objetivo primeiro seja a perspectiva ideológica. Seria considerar a História como os pós-modernos gostariam: uma estrutura discursiva meramente. Então, como raciocinar sobre o referente de obras literárias consideradas fontes da História ou documentos dentro da perspectiva historiográfica? Como abarcar a realidade a partir de obras que mantêm referentes inventados, fictícios, mesmo que inventados a partir da realidade? E, mais importante ainda, o que fazer com obras literárias decididamente de ruptura com essa invenção de verossimilhança externa ou de uma "correspondência" com o real? Obras que poderíamos chamar de fantásticas ou maravilhosas ou ambíguas ou delirantes ou ininteligíveis ou...? Se a cada um cabe uma efetivação do discurso fora de qualquer referência "real", para quê manter um discurso como representação? O que ele pode representar senão outros discursos? E a História seria a História dos discursos?

Essa é a razão de nossa insistência nos elementos internos da obra literária. Se a obra se configura, e sempre se configura, a partir da lógica social de um tempo, ela é fundamentalmente histórica. A cada tempo, obras pertinentes, que só poderiam surgir nesse mesmo tempo: uma Clarice Lispector não surgiria em 1300. Não que seus conteúdos, especialmente suas histórias narradas não fossem plausíveis àquele tempo, mas porque tanto os conflitos quanto as contradições e, especialmente, a forma como ela dispõe esses conteúdos ainda não estava disponibilizada lá, não pertencia à lógica desse tempo. Logo, a representação de uma obra, quer o autor queira, quer não, configura um tempo histórico. A Divina Comédia de Dante tinha por disposição uma lógica ptolomaica e foi dentro dessa lógica que ele ergueu seu portento de obra.

Um analítico da linguagem, estruturalista ferrenho, Louis Hjelmslev ${ }^{30}$, nos idos de 1940 do século passado, ajuda a clarear isso. Para ele, as noções de expressão e conteúdo comportam, cada uma delas, duas outras noções: a de forma e substância. Há, portanto, uma forma e substância da expressão e uma forma e substância do conteúdo. Conflitos, contradições, estórias, comportamentos, afetos, sensibilidades são substâncias que só ganham conteúdo quando dispostas numa forma, que implica seleção e, principalmente, estruturação.

\footnotetext{
${ }^{30}$ HJELMSLEV, Louis. Prolegómenos a una teoria del lenguaje. Madrid: Editorial Gredos, 1971.
} 
A Retórica Antiga falava de inventio, ordenada numa dispositio e numa elocutio. Sem isso, não há sequer discurso.

O que a forma final do conto "Bonde" de Trevisan nos informa a partir da breve análise que dele fizemos - principalmente a elipse como formalização e a mistura de temporalidades e espacialidades - é uma inferência que está além da própria representação dos conteúdos, que tem a ver com a noção de História do tempo presente ou, pelo menos, com a maneira como o homem de hoje vivencia essa História: sem sentido, o homem comum e insignificante que é José fantasia até para tornar-se um herói e sair de sua impotência, ou dar conta de si mesmo e de sua própria história frente a uma História que deixou de ser coletiva.

Finalizando, cremos que a prática da avaliação da História pela Literatura deve ser contornada pelo menos, entre outras, pelas três categorias que demarcamos: literatura e sociedade de entorno, forma externa; literatura e mundo representado, forma interna mediadora; e literatura e forma literária, forma interna.

\section{Referências Bibliográficas}

ADORNO, Theodor. "Palestra sobre lírica e sociedade". . Notas de literatura I. São Paulo: Duas Cidades; Editora 34, 2003.

ALBÉRÈS, Michel. Histoire du roman moderne. Paris: Albin Michel, 1962. (Tradução compilada de Albertina Vicentini).

ALBUQUERQUE JÚNIOR, Durval Muniz. "A dimensão retórica da historiografia”. PINSKY, Carla B. e LUCA, Tânia Regina de (orgs.). O historiador e suas fontes. São Paulo: Contexto 2011.

BAKHTIN, Mikhail. Marxismo e filosofia da linguagem. 12 ed. São Paulo: Hucitec, 2006.

BARTHES, Roland. "Da História ao real"; "O efeito do real". . O rumor da língua. São Paulo: Martins Fontes, 2004.

BENJAMIN, Walter. Obras escolhidas. 3 ed. São Paulo: Brasiliense, 1987.

BENVENISTE, Émile. "O aparelho formal da enunciação." Problemas de linguística geral II. Campinas, São Paulo: Pontes, 1989.

CANDIDO, Antonio. "Dialética da malandragem". Disponível em: http://www.revistas.usp.br/rieb/article/view/69638. Acesso em 13 de maio 2016. . Literatura e sociedade. Rio de Janeiro: Ouro sobre Azul, 2006. 
CARDOSO, Sílvia Helena Barbi. A questão da referência. Campinas, SP: Autores Associados, 2003.

CEVASCO, M.E. O diferencial da crítica materialista. Ideias, Campinas (SP), n.7, nova série, 2o. Semestre, 2013.

CHARTIER, Roger. A História cultural - entre práticas e representações. Lisboa; Rio de Janeiro: Difel; Bertrand do Brasil, 1990.

DE CERTEAU, Michel. A escrita da História. 2 ed. Rio de Janeiro: Forense Universitária, 2008.

EAGLETON, Terry. Ideologia. Uma introdução. São Paulo: Unesp, 1997.

FOUCAULT, Michel. Arqueologia do saber. 7 ed. Rio de Janeiro: Forense Universitária, 2007.

FRYE, Northrop. "Novas direções do passado"; "O imaginativo e o imaginário".

Fábulas de identidade. São Paulo: Nova Alexandria, 2000.

HJELMSLEV, Louis. Prolegómenos a una teoria del lenguaje. Madrid: Editorial Gredos, 1971.

JOLLES, André. Formas Simples. São Paulo: Cultrix, 1978.

NASCIMENTO, Naira de Almeida. "Ficção histórica contemporânea: desdobramento e deslocamento". WEINHARDT, Marilene. (org.) Fiç̧ão histórica: teoria e crítica. Ponta Grossa: UEPG, 2011.

RICOEUR, Paul. Tempo e narrativa. Campinas, São Paulo: Papirus, 1997.

SAUSSURE, Ferdinand. Curso de linguística geral. São Paulo: Cultrix, 1972.

SCHNEIDER, Peter. "A luz no fim do narrar". SERUYA, Teresa (org.). Sobre o romance no século XX. Lisboa: Colibri, 1995.

TREVISAN, Dalton. Desastres do amor. Rio de Janeiro: Civilização Brasileira, 1968.

VEYNE, Paul. Como se escreve a História. Lisboa: Edições 70, 1987.

WEINHARDT, Marilene. "Romance histórico: das origens escocesas ao Brasil finissecular". . (org.) Ficção histórica: teoria e crítica. Ponta Grossa: UEPG, 2011.

WHITE, Hayden. Meta-história: a imaginação histórica do século XIX. São Paulo: Edusp, 1992. 